\title{
SWORD OF ENDODONTIST: A REVIEW
}

\author{
Sangam Mittal ${ }^{1}$, Navneet Kukreja ${ }^{2}$, Devendra Chaudhary ${ }^{3}$, Abhishek Bansal ${ }^{4}$, Jyoti Bansal ${ }^{5}$, Disha Agarwal ${ }^{6}$ \\ ${ }^{1}$ PG Student, Department of Conservative Dentistry \& Endodontics, MM College of Dental Sciences \& Research, Haryana, India \\ ${ }^{2}$ Professor, Department of Conservative Dentistry \& Endodontics, MM College of Dental Sciences \& Research, Haryana, India \\ ${ }^{3}$ Professor \& HOD, Department of Conservative Dentistry \& Endodontics, Maharaja Ganga Singh Dental College, Rajasthan, India \\ ${ }^{4}$ Reader, Department of Conservative Dentistry \& Endodontics, MM College of Dental Sciences \& Research, Haryana, India \\ ${ }^{5}$ Reader, Department of Periodontics, MM College of Dental Sciences \& Research, Haryana, India \\ ${ }^{6}$ PG Student, Department of Conservative Dentistry \& Endodontics, MM College of Dental Sciences \& Research, Haryana, India
}

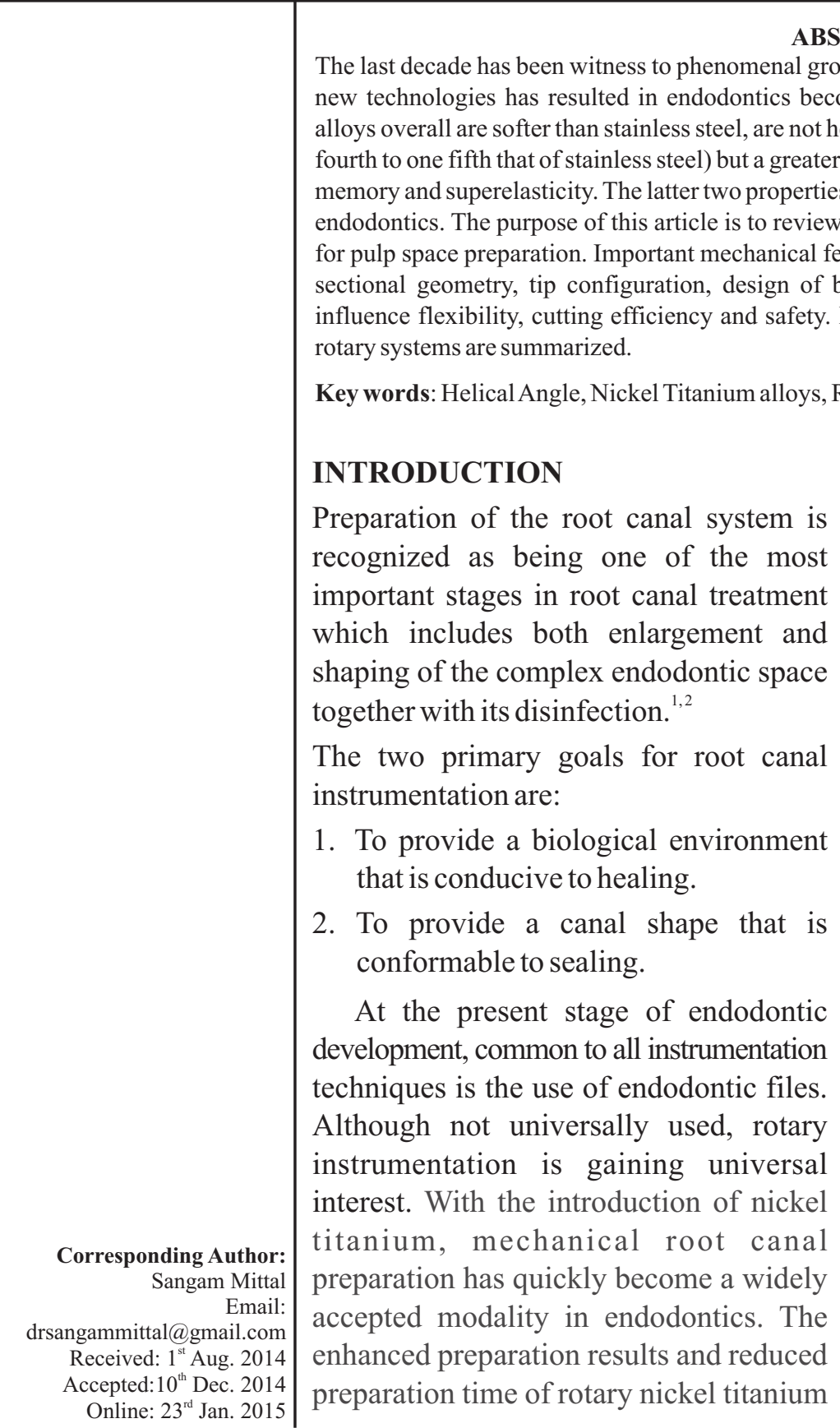

files have prompted the rapid adoption of rotary instrumentation. Yet, inspite of added advantages and excellent canal cleaning and shaping ability, a lack of information has caused the formulation of techniques that limited the comprehensive benefits of rotary instrumentation. ${ }^{3}$

Understanding the ramifications of file and technique design relative to canal anatomy enables the dentist to consistently achieve the most expeditious and excellent treatment with the least risks.

The K-type steel file has remained the instrument of choice for preparing root canals for over three quarters of a century. ${ }^{4}$ Instrumentation with stainless steel files has been shown to produce undesirable results in canals regardless of the technique or file type used. $^{5}$ Problems with breakage and the inflexibility of stainless steel instruments have resulted in a search for new materials from which to fabricate endodontic instruments. Civjan was one of the first investigators to propose nickel titanium 
(Ni-Ti) alloy for use in endodontics in 1975. Walia in 1988 evaluated the physical properties of some of the first Ni-Ti files that were machined from orthodontic wire. ${ }^{6}$

Recent advances in technology have permitted the manufacture of endodontic files from Nitinol, a nickel-titanium alloy with a very low modulus of elasticity. ${ }^{7}$ Over the last few years, endodontics has undergone a complete revolution with the use of these Nickel-Titanium alloys for the manufacture of manual instruments initially and then rotary endodontic instruments. ${ }^{4,8}$

The extraordinary characteristics of superelasticity, shape memory and strength of Ni-Ti alloy have made it possible to manufacture rotary instruments with double, triple and quadruplet taper compared to the traditional standard. This has made it possible to achieve perfect shaping with the use of very few instruments and in a short period of time. ${ }^{8}$

The cutting ability of root canal instruments is a complex interrelationship of different parameters such as cross-sectional design, chip removal capacity, helical and rake angle, metallurgical properties, and surface treatment of the instruments. ${ }^{9}$

It has become important for today's practitioner to understand some important design features of these rotary files. In using any file design, understanding the rudimentary physics involved in its use is imperative for the practitioner to take full advantage of its benefits. Recognition of instrument features that improve usefulness or pose possible risks must also be achieved. Figure 1 shows various components of a Rotary file.

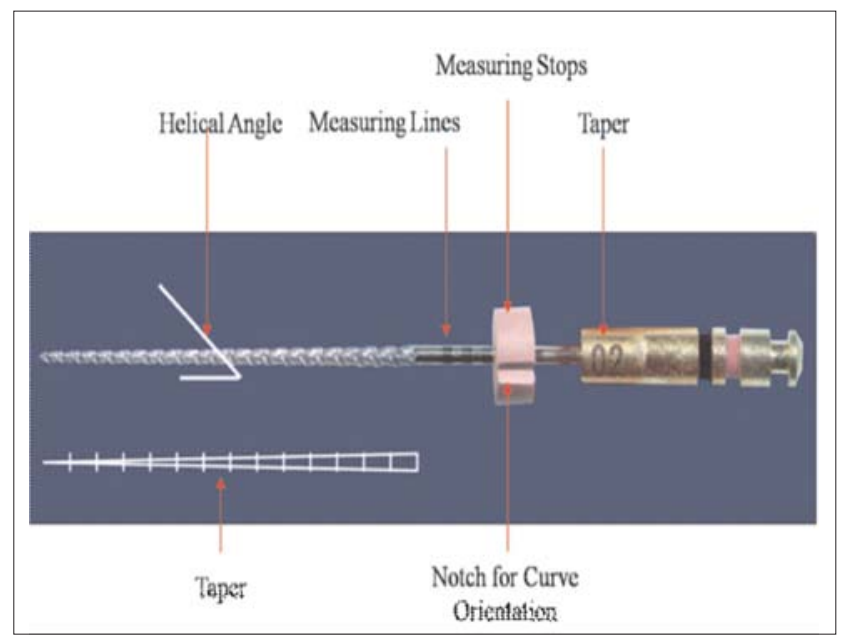

Figure 1: Various components of a Rotary file

\section{Taper}

Taper is a feature of file design which is particularly important concerning "system concepts." The taper is usually expressed as the amount the file diameter increases each millimeter along its working surface from the tip toward the file handle. ${ }^{10,11}$

For example, a size 25 file with a 0.02 taper would have a $0.27 \mathrm{~mm}$ diameter $1 \mathrm{~mm}$ from the tip, a $0.29 \mathrm{~mm}$ diameter $2 \mathrm{~mm}$ from the tip, and a $0.31 \mathrm{~mm}$ diameter $3 \mathrm{~mm}$ from the tip. Some manufacturers express the taper in terms of percentage in which case the 0.02 taper becomes a $2 \%$ taper. Historically, as an ISO standard, a file was fluted and tapered at $2 \%$ for 16 $\mathrm{mm}$, but now files incorporate a wide variation of lengths and tapers of working surface (Figure 2).

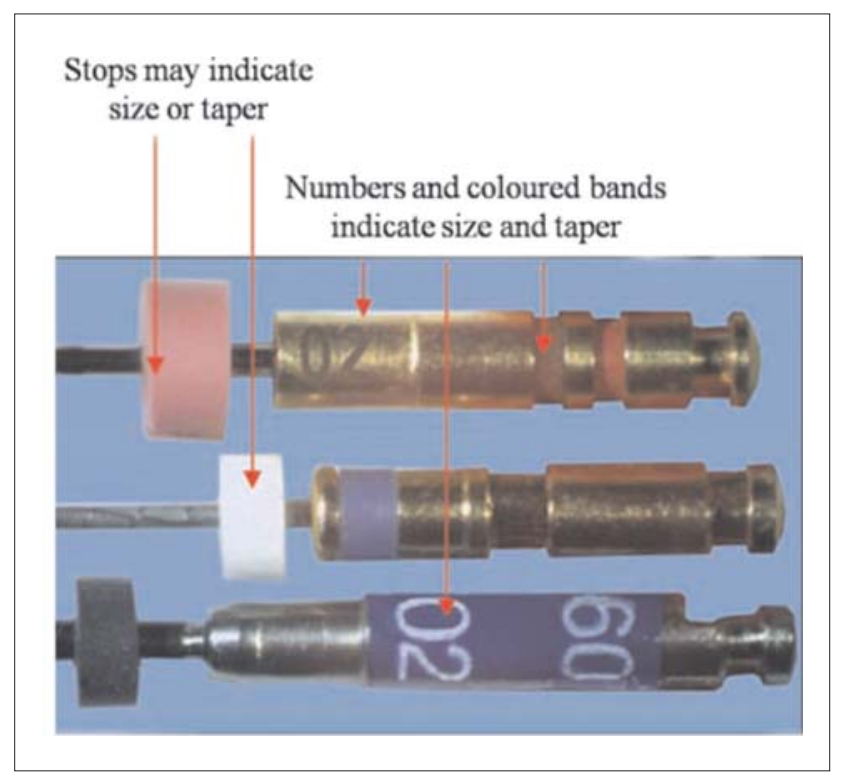

Figure 2: Taper indicators on a Rotary file

We have two basic options when instrumenting a root canal. First, we can instrument a root canal by using files of the same taper but with varying apical tip diameters. An example of this would be hand files that all have a consistent taper (0.02) but with various tip diameters. A rotary file of constant taper would be the 0.04 taper Profile that has a constant taper (0.04) but has varying apical tip diameters.

Secondly, there is the school of thought that prefers varying or graduating tapers. ${ }^{12,13}$ These files have the same apical tip size but their taper varies from 0.04 to 0.12 . The popular GT series of files employs a varying taper while the Quantec files use a graduated increase in taper. ${ }^{14},{ }^{15}$ The idea behind variable or graduating tapers is that each successive file is only 
engaging a minimal aspect of the canal wall. Therefore, frictional resistance is reduced and requires less torque to properly run the file. We also have a file (the ProTaper) that features a progressive taper along its shank. One of the benefits of such a design, according to the manufacturer, is reduced torsional loading. ${ }^{3}$

\section{Flute}

The flute of the file is the groove in the working surface used to collect soft tissue and dentine chips removed from the wall of the canal (Figure 3 ). The effectiveness of the flute depends on its depth, width, configuration and surface finish. ${ }^{3}$

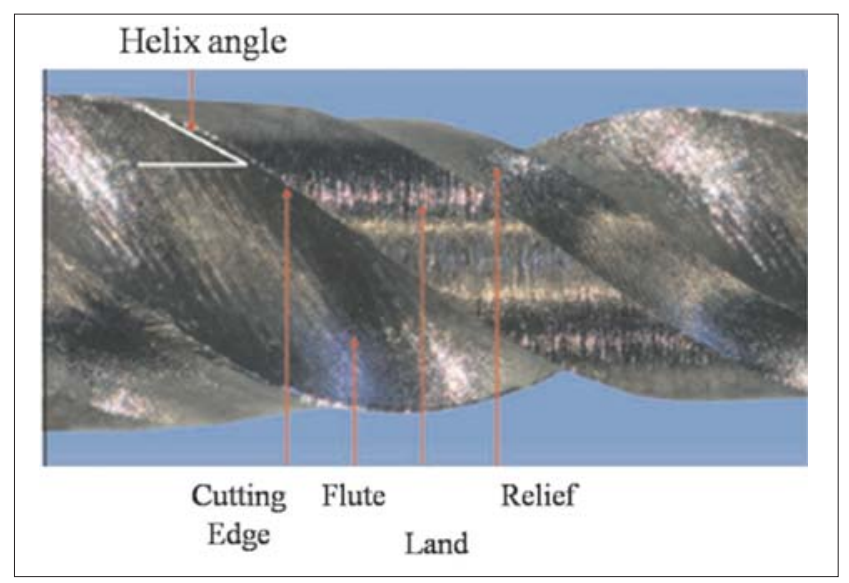

Figure 3: Quantec File

\section{Cutting Edge}

The surface having the greatest diameter that follows the groove (defined as where the flute and land intersect), as it rotates, forms the leading (cutting) edge, (Figure 3) or the blade of the file that forms and deflects chips from the wall of the canal and severs or snags soft tissue. Its effectiveness depends on its angle of incidence and sharpness.

\section{Land}

If there is a surface that projects axially from the central axis as far as the cutting edge, between flutes, this surface is called the land or radial land (Figure 3) (sometimes called the marginal width). The land reduces the screwing-in tendency of the file, reduces transportation of the canal, decreases the propagation of micro-cracks on its circumference, gives support to the cutting edge, and limits the depth of cut. Its position relative to the opposing cutting edge and its width determine its effectiveness. ${ }^{3,16}$

Previously, rotary files either had full radial lands (Profile, GT) (Figure 4a) or their lands were recessed (Quantec) (Figure 4b). However, there still exists some controversy over what is the best type of land. Advocates of a full land feel such a design effectively keeps the file centered, while proponents of a recessed land feel such engineering allows for less frictional resistance. ${ }^{3,16}$

The K3 land (Figure 4c) design is unique and addresses the challenge of combining core and peripheral strengths. The K3, like the Profile, is a three fluted file with three lands. However, two of the lands are broad and recessed, while the third one is a narrow full land. The brilliance of this design is that the relieved portion of the recessed lands minimizes resistance while the extended width maximizes strength. Additionally, the combination of the three lands keeps the file centered in the canal. ${ }^{3,16}$

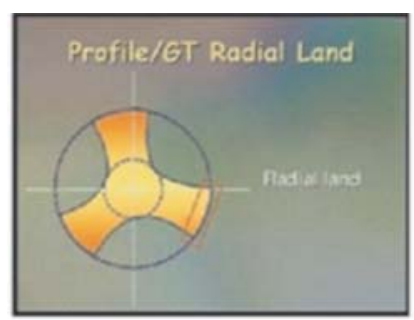

Figure 4a: Full radial land (Profile, GT)

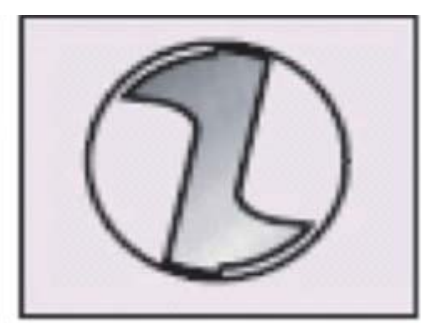

Figure 4b: Recessed lands (Quantec)

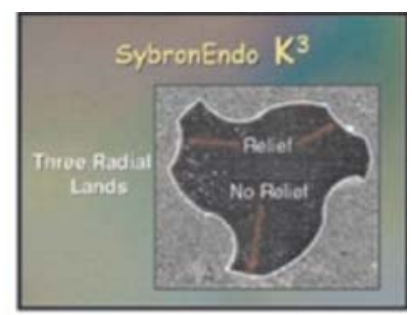

Figure 4c: K3 with Three Radial Land

The chance of transporting a root canal with a rotary file that has a non-cutting tip and radial lands is minimal. There is an important concept of rotary instrumentation that should be remembered. The concept is not of "drilling" a hole in a root. Rather, it is one of taking a small hole, planing the inside, and making it larger. However, two of the third generation files (ProTaper and $\mathrm{RaCe}$ ) do not have the benefit of radial lands. ${ }^{17}$

\section{Advantages of Land}

- Reduce the torque requirements of the file,

- Keeps file centred in canal.

\section{Disadvantages of Land}

- Makes file less sharper \& less efficient 
- Decreased flexibility of file due to increased metal thickness.

\section{Relief}

In order to alleviate frictional resistance or abrasion resulting from a land, some of the surface area of the land that rotates against the canal wall may be reduced to form the relief (Figure 3 ). ${ }^{3}$

\section{Helical Angle}

The angle that the cutting edge makes with the long axis of the file is called the helix angle (Figure 3) and serves to auger debris collected in the flute from the canal. By definition, the helical angle is the angle that the cutting edge makes with the long axis of the file. The first rotary file to take advantage of this factor was the GT. As a rotary file works in a canal, the dentinal debris needs to be removed quickly and effectively. ${ }^{3}$

Files with a constant helical flute angle allow debris to accumulate, particularly in the coronal part of the file.

Additionally, files that maintain the same helical angle along the entire working length will be more susceptible to the effect of "screwing in" forces. By varying the flute angles, debris will be removed in a more efficient manner and the file will be less likely to screw into the canal. ${ }^{18}$ For example, in the $\mathrm{K} 3$, the helical angle increases from the tip to the handle. The result of this design is more successful channelling that allows for superior debris removal.

The RaCe file is unique and utilizes an "alternating helical design" that reduces rotational torque by using spiralled and non spiralled portions along the working length. This design feature also reduces the tendency of the file to get "sucked into" the canal.

\section{Core}

The core is the cylindrical center part of the file having its circumference outlined and bordered by the depth of the flutes. The flexibility and resistance to torsion is partially determined by the core diameter. The core taper and total external taper can be different and the relative diameter of the core, compared to the file's total diameter, may vary along its working portion in order to change the flexibility and resistance to torsion. The importance of the ratio of core diameter to total diameter is often overlooked in predicting a file's susceptibility to failure and can be different for each file size of the same series.

\section{Rake Angle}

Rake angles are also important and affect the cutting efficiency of the instrument. There remains confusion over what constitutes a rake angle and what is the cutting angle. The rake angle is the angle formed by the cutting edge and a cross section taken perpendicular to the long axis of the instrument. The cutting angle, on the other hand, is the angle formed by the cutting edge and a radius when the file is sectioned perpendicular to the cutting edge. ${ }^{3,8}$

Positive rake angles (Figure 5a) will cut more efficiently than neutral rake angles, which scrap the inside of the canal. Most conventional endodontic files utilize a negative or "substantially neutral" rake angle. A negative rake angle (Figure 5b) is least aggressive but the cutting efficiency of a file can also be affected by the blank design. For example, the ProTaper has a negative rake angle but due to its modified $\mathrm{K}$ blade and progressive taper, the instrument cuts very effectively. ${ }^{3}$

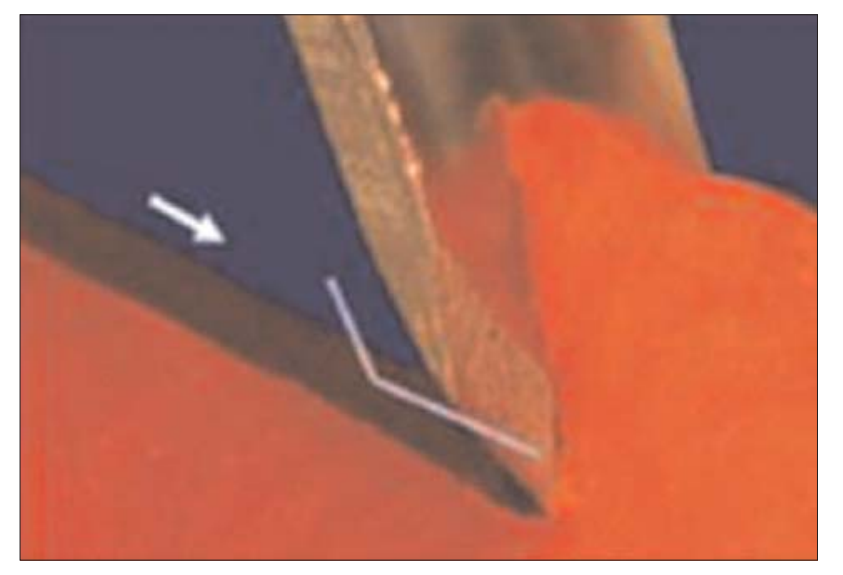

Figure 5a: Positive Rake Angle (Obtuse Angle)

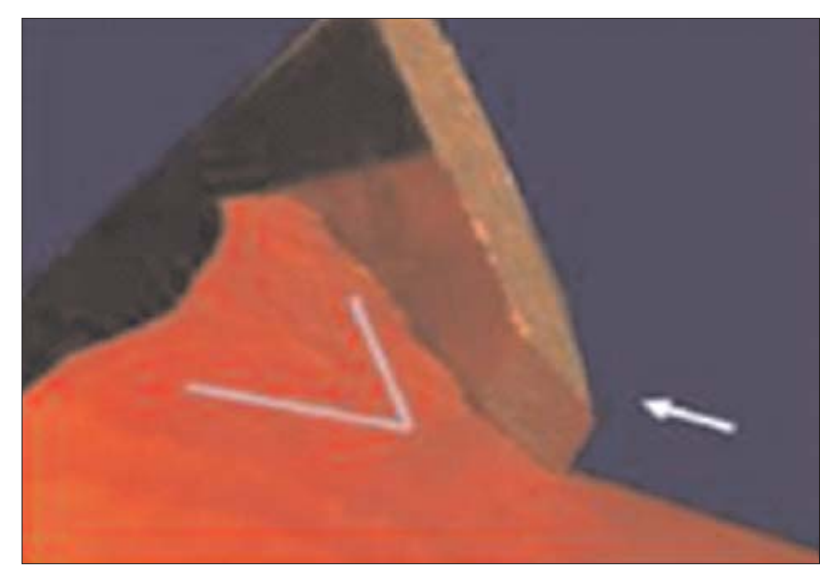

Figure 5b: Negative Rake Angle (Acute Angle) 
However, many practitioners believe the ideal rake angle is, in fact, slightly positive but not overly positive. An overly positive rake angle will result in digging and gouging of the dentin. This can lead to separation.

The K3 is the only third generation file to feature a slightly positive rake angle. This results in optimum cutting efficiency. Part of the success of this new file can be attributed to the new manufacturing capability that allows the manufacturer to produce files with a consistent, slightly positive rake angle. This precision and consistency was difficult to achieve with the previous technology. ${ }^{1,3,8}$

\section{Pitch}

Pitch is the number of spirals or threads per unit length. Screws historically have had a constant pitch. The result of a constant pitch and constant helical angles is a "pulling down" or "sucking down into" the canal. This is particularly significant in rotary instrumentation when using files with a constant taper. ${ }^{19}$

However, one file, the K3, has addressed this issue. This file has purposely been designed with constant tapers but with variable pitch and helical angles. The result is a dramatic reduction in the sense of being "sucked down into" the canal. This is very significant, especially when performing a fully tapered 0.06 preparation.

Examples of variable pitch, helical angle \& constant taper [in each file]: GT, RaCe, K 3, Mtwo, HERO 642, Endowave.

Their variable pitched flutes provide a reamer like efficiency at the shank and K-file strength at the tip. Examples of variable pitch, helical angle \& progresive taper [in each file]: Protaper.

\section{Tip}

Most dentists are best served by using a rotary file with a non-cutting tip (Figure 6a). Cutting tips on rotary files make them too aggressive. A cutting tip (Figure 6b) has the ability to enter narrow, somewhat calcified canals, but has two serious concerns. The first is if a cutting tip goes beyond, upon retraction of the file, it will create an elliptical tear. ${ }^{3}$

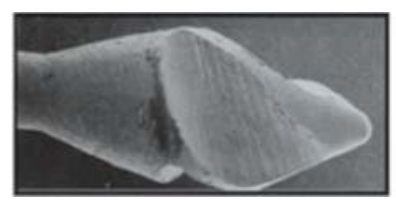

Figure 6a: Non- cutting Tip

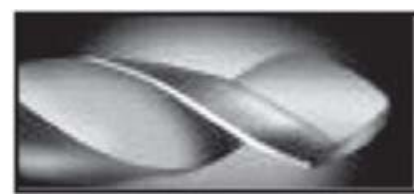

Figure 6b: Cutting Tip
This is very difficult to repair and obturate when one accidentally go past the end of the tooth. However, going beyond with a non-cutting tip will create a concentric circle at the end of the root. These are easily filled with a non-standardized cone.

Secondly, if a cutting tip is placed on a nonlanded file, it will have the distinct possibility of transportation. This is especially true if the file is held at same length for any period of time. Theoretically, a cutting tip will not transport if it goes to length and is immediately retracted. Established files such as the Profile and the GT, along with the new K3, employ a non- cutting tip. Two of the new third-generation rotaries (ProTaper and the $\mathrm{RaCe}$ ) have cutting tips. Even the manufacturer for the ProTaper recommends that the file does not stay at working length for more than one second. This gives you a slim margin for error. $^{3,4}$

However, the use of cutting tips is limited and they should only be used in the hands of an experienced clinician. Some files claim to have "modified cutting tips" or "partially active" tips. But these are just fake marketing views. So the tip is either a cutting tip or it is not.

Table 1, 2 \& 3 shows basic features of some currently available rotary file systems.

\section{CONCLUSION}

The choice of a specific rotary system for daily use requires consideration of the combined evaluation of all described parameters. The question arises that what is the best design and which is the superior file. It really depends upon the working condition like position of tooth in the arch, number of roots and root canals, size of pulp space, degree and level of curvatures of root canal. One thing we can say with confidence is that before you choose a rotary file, you must try it. Understanding the fundamentals of file design and combining that with your pre-clinical trial will facilitate making the correct choice in rotary files. Keep in mind, that as you become more experienced your expectations of rotary files will change. Eventually, you will realize there is a place in the endodontic 
Table 1: Basic features of rotary file systems

\begin{tabular}{|c|c|c|c|c|c|}
\hline Feature & Lightspeed & Profile & Quantec & Hero & Race \\
\hline COMPANY & Sybron Endo & Tulsa Dental & SybronEndo & Micro-Mega & FKG Dentaire \\
\hline RANGE OF TIP SIZES & $\# 20$ to $\# 140$ & $\# 15$ to $\# 90$ & ISO tip sizes & $\# 20$ to $\# 45$ & $\# 15$ to $\# 40$ \\
\hline TAPERS AVAILABLE & Taperless shafts & $2 \%, 4 \%, 6 \%$ & $2 \%$ to $12 \%$ & $2 \%, 4 \%, 6 \%$ & $2 \%$ to $10 \%$ \\
\hline CROSS-SECTION & U shaped & Triple U shaped & Double helical & $\begin{array}{l}\text { Triple Helix } \\
\text { geometry }\end{array}$ & Triangular \\
\hline RADIAL LANDS & $\begin{array}{l}3 \text { radial lands } \\
\text { present }\end{array}$ & $\begin{array}{l}3 \text { radial lands } \\
\text { present }\end{array}$ & $\begin{array}{l}2 \text { recessed radial } \\
\text { lands present }\end{array}$ & Absent & Absent \\
\hline TIP TYPE & $\begin{array}{l}\text { Non-cutting pilot } \\
\text { tip }\end{array}$ & $\begin{array}{l}\text { Non-cutting } \\
\text { bullet nose tip }\end{array}$ & $\begin{array}{l}\text { QLX : Non- } \\
\text { cutting tip; QSE : } \\
\text { Cutting tip }\end{array}$ & Inactive & Cutting tip \\
\hline RAKE ANGLE & Negative & $-20^{\circ}$ & Positive & Positive & Negative \\
\hline LENGTHS AVAILABLE & $21,25,31,50 \mathrm{~mm}$ & $\begin{array}{l}21,25,31 ; \mathrm{OS}- \\
19 \mathrm{~mm}\end{array}$ & $\begin{array}{l}21,25 ; \text { Orifice } \\
\text { opener }-17 \mathrm{~mm}\end{array}$ & 21,25 & $19,21,25,28,31$ \\
\hline TECHNIQUE USED & $\begin{array}{l}\text { Crown down } \\
\text { technique }\end{array}$ & $\begin{array}{l}\text { Crown down } \\
\text { technique }\end{array}$ & $\begin{array}{l}\text { Modified Crown } \\
\text { down technique }\end{array}$ & $\begin{array}{l}\text { Crown down } \\
\text { technique }\end{array}$ & $\begin{array}{l}\text { Step back } \\
\text { technique or } \\
\text { Crown down } \\
\text { technique }\end{array}$ \\
\hline SPEED RANGE & $1500-2000 \mathrm{rpm}$ & $150-300 \mathrm{rpm}$ & $300-350 \mathrm{rpm}$ & $500-600 \mathrm{rpm}$ & $300-600 \mathrm{rpm}$ \\
\hline $\begin{array}{l}\text { AVAILABLE IN HAND } \\
\text { FILES }\end{array}$ & No & Yes & No & Yes & Yes \\
\hline HELICAL ANGLE & Constant & Constant & Variable & Constant & Variable \\
\hline
\end{tabular}

Table 2: Basic Features Of Rotary File Systems

\begin{tabular}{|c|c|c|c|c|c|}
\hline Feature & Protaper & K3 & Hyflex & Twisted files & Revo-s \\
\hline COMPANY & $\begin{array}{l}\text { Dentsply } \\
\text { Mailefer }\end{array}$ & Sybron Endo & $\begin{array}{l}\text { Coltene } \\
\text { Whaledent }\end{array}$ & Sybron Endo & Micro - Mega \\
\hline $\begin{array}{l}\text { RANGE OF TIP } \\
\text { SIZES }\end{array}$ & $\# 17$ to $\# 50$ & $\# 15$ to $\# 60$ & $\# 8$ to $\# 80$ & $\# 25$ to $\# 50$ & $\# 25$ to $\# 40$ \\
\hline $\begin{array}{l}\text { TAPERS } \\
\text { AVAILABLE }\end{array}$ & $\begin{array}{l}\text { Progressively } \\
\text { variable }\end{array}$ & $2 \%$ to $10 \%$ & $4 \%$ to $8 \%$ & $4 \%$ to $12 \%$ & $6 \% \& 4 \%$ \\
\hline ROSS-SECTION & $\begin{array}{l}\text { Convex } \\
\text { Triangular } \\
\end{array}$ & $\begin{array}{l}\text { Asymmetric } \\
\text { cross-section }\end{array}$ & Symmetrical & Triangular & Asymmetrical \\
\hline RADIAL LANDS & Absent & $\begin{array}{l}3 \text { radial lands } \\
\text { present }\end{array}$ & Absent & Absent & Absent \\
\hline TIP TYPE & $\begin{array}{l}\text { Modified guiding } \\
\text { tip }\end{array}$ & Safe cutting tip & $\begin{array}{l}\text { Non - Cutting } \\
\text { tip }\end{array}$ & $\begin{array}{l}\text { Non-cutting } \\
\text { pilot tip }\end{array}$ & Inactive tip \\
\hline RAKE ANGLE & Positive & Positive & Negative & Positive & \\
\hline $\begin{array}{l}\text { LENGTHS } \\
\text { AVAILABLE }\end{array}$ & $19,21,25$ & $21,25,30$ & 21,25 & 23,27 & $21,25,29$ \\
\hline $\begin{array}{l}\text { TECHNIQUE } \\
\text { USED }\end{array}$ & $\begin{array}{l}\text { Coronal then } \\
\text { apical sequential }\end{array}$ & $\begin{array}{l}\text { Crown down } \\
\text { technique }\end{array}$ & $\begin{array}{l}\text { Crown down } \\
\text { technique \& } \\
\text { apical } \\
\text { enlargement }\end{array}$ & $\begin{array}{l}\text { Crown down } \\
\text { technique }\end{array}$ & $\begin{array}{l}\text { Crown down } \\
\text { technique }\end{array}$ \\
\hline SPEED RANGE & $150-350 \mathrm{rpm}$ & $300-350 \mathrm{rpm}$ & $500 \mathrm{rpm}$ & $500 \mathrm{rpm}$ & $250-400 \mathrm{rpm}$ \\
\hline $\begin{array}{l}\text { AVAILABLE IN } \\
\text { HAND FILES }\end{array}$ & Yes & No & No & No & Yes \\
\hline $\begin{array}{l}\text { HELICAL } \\
\text { ANGLE }\end{array}$ & Variable & Variable & Constant & Variable & Constant \\
\hline
\end{tabular}


Table 3. Basic Features of Rotary File Systems

\begin{tabular}{|c|c|c|c|c|c|}
\hline Feature & Endosequence & MTWO & Reciproc & Waveone & Protaper next \\
\hline COMPANY & Brasseler & VDW & VDW & $\begin{array}{l}\text { Dentsply } \\
\text { Maillefer }\end{array}$ & Dentsply \\
\hline $\begin{array}{l}\text { RANGE OF TIP } \\
\text { SIZES }\end{array}$ & $\# 15$ to $\# 50$ & $\# 10$ to $\# 60$ & $\# 25, \# 40, \# 50$ & $\# 21, \# 25, \# 40$ & $\begin{array}{l}\# 17, \# 25, \# 30 \text {, } \\
\# 40, \# 50\end{array}$ \\
\hline $\begin{array}{l}\text { TAPERS } \\
\text { AVAILABLE }\end{array}$ & $4 \%, 6 \%$ & $4 \%$ to $7 \%$ & $8 \%, 6 \%, 5 \%$ & $6 \%, 8 \%$ & Variable \\
\hline CROSS-SECTION & Asymmetrical & $\begin{array}{l}\text { Italic S - } \\
\text { shaped }\end{array}$ & S-shaped & $\begin{array}{l}\text { Modified } \\
\text { Convex } \\
\text { Triangular }\end{array}$ & $\begin{array}{l}\text { Off centered } \\
\text { rectangular }\end{array}$ \\
\hline RADIAL LANDS & No & Absent & No & Present & Absent \\
\hline TIP TYPE & Non - cutting & $\begin{array}{l}\text { Safe ended tip } \\
\text { design }\end{array}$ & $\begin{array}{l}\text { Non - cutting } \\
\text { tip }\end{array}$ & $\begin{array}{l}\text { Non-cutting } \\
\text { pilot tip }\end{array}$ & $\begin{array}{l}\text { Rounded safe } \\
\text { tip }\end{array}$ \\
\hline RAKE ANGLE & Positive & Positive & Absent & Neutral & Positive \\
\hline $\begin{array}{l}\text { LENGTHS } \\
\text { AVAILABLE }\end{array}$ & $21,25,31$ & $21,25,31$ & $21,25,31$ & $21,25,31$ & $21,25,31$ \\
\hline $\begin{array}{l}\text { TECHNIQUE } \\
\text { USED }\end{array}$ & $\begin{array}{l}\text { Crown down } \\
\text { technique }\end{array}$ & $\begin{array}{l}\text { Crown down } \\
\text { technique }\end{array}$ & $\begin{array}{l}\text { Single file } \\
\text { technique }\end{array}$ & $\begin{array}{l}\text { Balanced force } \\
\text { technique }\end{array}$ & $\begin{array}{l}\text { Crown Down } \\
\text { technique }\end{array}$ \\
\hline SPEED RANGE & $150-175 \mathrm{rpm}$ & $300 \mathrm{rpm}$ & $\begin{array}{l}10 \text { cycles of } \\
\text { reciprocation / } \\
\text { second }\end{array}$ & $350 \mathrm{rpm}$ & $300 \mathrm{rpm}$ \\
\hline $\begin{array}{l}\text { AVAILABLE IN } \\
\text { HAND FILES }\end{array}$ & No & No & No & Yes & No \\
\hline $\begin{array}{l}\text { HELICAL } \\
\text { ANGLE }\end{array}$ & Constant & Variable & Constant & Variable & Variable \\
\hline
\end{tabular}

armamentarium for many of these file designs. The ultimate goal is to be able to confidently offer patient a root canal procedure, which will hold up long term and be of equal or greater longevity than that of an implant.

\section{REFERENCES}

1. Ruddle CJ. Cleaning and shaping the root canal system. In: Cohen S, Burns RC, 9th eds. Pathways of the Pulp. St Louis: Mosby, 2006.

2. Hulsmann M, Peters OA, Dummer MH. Mechanical preparations of root canals: shaping goals, techniques and means. Endo Topics 2005; 10(1): 30-76.

3. McSpadden JT. Mastering Endodontic Instrumentation. Canada: Cloudland Institute; 2007.

4. Castelucci A. Endodontics Volume II. Florence: IL Tridente Edizioni Odontoiatriche; 2009. p588-604.

5. Weine FS, Kelly RF, Lid PJ. The effect of preparation procedures on original canal shape and on apical foramen shape. JEndod 1975; 1(8): 255-62.

6. Gambill JM, Alder M, Rio CE. Comparison of NickelTitanium and Stainless Steel Hand-File Instrumentation Using Computed Tomography. J Endodon 1996; 22(7): 369-375.

7. Esposito PT, Cunningham CJ. A Comparison of Canal Preparation with Nickel- Titanium and Stainless Steel Instruments. J Endod 1995; 21(4): 173-176.

8. Sanghvi Z, Mistry K. Design features of rotary instruments in endodontics. The Journal of Ahemdabad dental college and hospital 2011;2(1); 6-11.

9. Schäfer E, Oitzinger M. Cutting Efficiency of Five Different Types of Rotary Nickel-Titanium Instruments. J Endod 2008; 34(2): 198-200.
10. Ingle JI, Bakland LK, Baumgartner JC. Ingle's endodontics 6 . Hamilton, Ontario: BC Decker; 2008. p877-991.

11. Michael A. Nickel-titanium: options and challenges. Dent Clin NAm 2004; 48(1): 55-67.

12. Hulsmann M, Schade M, Schafer's F. A comparative study of root canal preparation using Profile 0.04 and Light Speed NiTi instruments. Int Endod J 2001; 34(7): 538-46.

13. Bergmans L, Van CJ, Beullens M, Wevers M, Van MB, Lambrechts P. Progressive versus constant tapered shaft design using NiTi rotary instruments. Int Endod J 2003; 36(4): 288-95.

14. Griffiths IT, Chassot AL, Nascimento MF, Bryant ST, Dummer PM. Canal shapes produced sequentially during instrumentation with Quantec SC rotary nickel-titanium instruments: a study in simulated canals. Int Endod J 2001; 34(2): 107-12.

15. Griffiths IT, Bryant ST, Dummer PM. Canal shapes produced sequentially during instrumentation with Quantec LX rotary nickel-titanium instruments: a study in simulated canals. Int Endod J 2000; 33(4): 346-54.

16. Schafer E, Tepel J. Relationship between design features of endodontic instruments and their properties. Part III. Resistance to bending and fracture. J Endod 2001;27(4): 299-303.

17. Paque F, Musch U, Huslmann M. Comparison of root canal preparation using RaCe and ProTaper rotary NiTi instruments. Int Endod J 2005; 38(1): 8-16.

18. Diemer F, Calas P. Effect of pitch length on the behavior of rotary triple helix root canal instruments. J Endod 2004; 30(10): 716-8.

19. Young GR, Parashos P, Messer HH. The principles of techniques for cleaning root canals. Aust. Dent. J. Supp. 2007; 52(1): 52-60. 